\section{Sir William Slingo}

THE death on January 19, at the age of seventynine years, of Sir William Slingo marks the passing of a distinguished civil servant and engineer, whose career has been associated with wide and farreaching developments in the art of communication.

At the age of fifteen years, Slingo entered the Post Office as a telegraphist, and twenty-eight years later was appointed to the Engineering Department, from which he eventually retired as engineer-in-chief in 1919 after a career in the civil service of nearly fifty years. During that period, which covered the growth of the trunk telephone system, the transfer of the National Telephone Company's plant to the State and the subsequent developments of telephony in Great Britain, Sir William Slingo played a very active part. He was primarily responsible for the compilation of an inventory of the National Telephone Company's plant on its acquisition by the State. On the basis of this inventory, an award of $12 \frac{1}{2}$ million pounds sterling was made to the Company instead of the twenty-one millions claimed.

Although at the outset Slingo was a telegraph engineer, at an early stage he proceeded to widen his outlook on telephone problems, and made substantial contributions to other branches of electrical engineering. He was responsible for the design and installation of one of the earliest electrical lighting plants in London, when he acted as consulting engineer to the Drapers Company for an installation at the East London People's Palace.

To Sir William Slingo's credit must be placed the achievement of building up the nucleus of an engineering staff from a group of telegraphists whose previous training was mainly that of manipulative skill. In doing this, he first made himself proficient in the art, and then for many years carried on single-handed the pioneer work of training the telegraph engineers of the future. He founded on his own initiative at the General Post Office, the Telegraphists School of Science, beginning with a handful of students, which had grown to 850 when he relinquished the post of principal. Many engineers of established reputation in the art of tele-communications received their earliest training in that school. Sir William Slingo's work during this period in furthering the study of telegraph and telephone engineering and placing it on a more scientific basis, at a much earlier date than otherwise would have been the case, exercised a wide influence; and, particularly in the development of telegraphy, British practice was largely followed in other countries.

After his retirement from the Post Office, Sir William continued to be actively engaged on communication work. Amongst other enterprises, on behalf of the Marconi Company he had acted as administrator general for the Peruvian system of posts, telegraphs and wireless services, a system which he reorganised and placed on a sound basis.

Sir William's professional reputation as an engineer was of the highest, but it is probable he will be best remembered and honoured by his early services in the training of telegraph engineers.
A. S. A.

\section{DR. JoHN HowaRd}

Dr. JoHN Howard, of the Fuel Research Station, Greenwich, was killed on January 3 through being caught by an avalanche and swept down a hillside in the neighbourhood of Vent. His companion was Mr. Kenneth F. Armstrong, who was also killed. Dr. Howard was the only son of Mr. and Mrs. Fred Howard. Mr. Fred Howard was formerly Mayor of Holborn.

John Howard was born in London and educated at Oundle School, where he specialised in history before going over to the seience side, and was head of Sydney House. In 1927 he became a scholar of Corpus Christi College, Oxford, and took his B.A. degree in 1930 and B.Sc. in 1931, being 'proxime' in the Gibbs scholarship in chemistry. His work was directed by Dr. Hammick, with whom he later published two papers. Whilst at College he became sergeant in the artillery battery of the Oxford University Officers Training Corps and obtained his Certificate B. In 1931 he gained a Commonwealth fellowship and worked at Princeton University with Prof. H. S. Taylor upon "The Adsorptive and Catalytic Properties of Chromium Oxide Gel". He submitted a thesis on this subject and was awarded his Ph.D. $\mathrm{He}$ published papers in association with Prof. Taylor. He took an active part in a number of sports, particularly in swimming, rugby, fives and shooting. He was captain of the school shooting team at Oundle and won the Stock Exchange Cup for shooting while at Oxford.

Dr. Howard was appointed to the staff of the Department of Scientific and Industrial Research in 1933, and was assigned for duty at the Fuel Research Station, where he commenced an investigation to determine the causes of the deterioration of catalysts in the hydrogenation process. He took a very broad view of the study of science, and his knowledge of history, which was inspired by his mother, who was a graduate in history at Manchester, aroused his interest in the general trends taking place in the fuel industry. As a result he was concentrating upon the effects of the economic changes upon the development of the uses of fuel, and he was acting as the personal assistant of the Director of Fuel Research. He had a very good knowledge of languages and had taken up the study of economics. He had a charming personality and had established a real friendship with his colleagues on the staff.

WE regret to announce the following deaths :

Prof. Oliver P. Jenkins, emeritus professor of physiology and histology in Stanford University, an authority on American fishes, on January 9, aged eighty-four years.

Prof. Hugo Junkers, founder and until 1932 head of the aircraft firm of that name at Dessau, who was a pioneer in the development of all-metal aircraft, on February 3, aged seventy-six years.

Prof. Emanuele Paternò, formerly professor of general chemistry in the University of Rome, and an honorary fellow of the Chemical Society. 